\title{
Genotypic Characterization of Indigenous Rhizobium Strain from Cultivated Cowpea (Vigna unguiculata L.) in Bangladesh
}

\author{
Ali Mohammad Nushair, Ananda Kumar Saha, Md. Anisur Rahman, \\ Moni Krishno Mohanta* and Md. Fazlul Haque \\ Genetics and Molecular Biology Laboratory, Department of Zoology, \\ University of Rajshahi, Rajshahi-6205, Bangladesh \\ *Corresponding author
}

\section{A B S T R A C T}

\begin{tabular}{|l|}
\hline K e y w o r d s \\
Rhizobium, \\
Cowpea, 16S rDNA \\
sequence, \\
Nodulation.
\end{tabular}

Keywords

Rhizobium,

Cowpea, 16S rDNA sequence,

21 September 2017

10 October 2017
A gram negative strain of Rhizobium sp. SOY7 has been isolated from root nodules of cow pea (Vigna unguiculata L.) which was later identified on the basis of biochemical tests and $16 \mathrm{~S}$ rDNA sequencing. The optimum culture condition of Rhizobium sp. SOY7 was determined at $\mathrm{pH} 7.0$ and $28^{\circ} \mathrm{C}$ temperature. The strain was resistant to most of the antibiotics used in this study except Tetracycline, Ceftazidime, Pefloxacin, Cotrimoxazole and Mecillinam. Moreover, the isolate was sensitive to the higher concentration of $\mathrm{NaCl}(>1 \%)$. The strain is capable to produce nodules when induced rhizobia as inoculants and resulted insignificant changes in plant growth characteristics. The most abundant nodulation and improved growth of the legumes were determined in plants inoculated with Rhizobium sp. SOY7 was statistically significant $(p<0.05)$ compared with uninoculated controls.

\section{Introduction}

Rhizobia are gram negative bacteria that exist in a symbiotic relationship with several grain legumes as a host plants (Ngakou et al., 2009). In this association, the host plant provides the bacteria symbiont with sugars and a protected environment, while the bacteria fix nitrogen from the air and make it available to the plant in the form of ammonia (Kiers et al., 2002).Legumes are an inexpensive food, commonly found in diets all over the world and that can provide proteins for human beings. In Bangladesh where the population diet is mostly based on legumes, there is need to improve the production of common legumes through inoculation technology, if full benefit from these crops is to be achieved in terms of maximum yield and soil fertility. However, the yield of cowpea is very poor in Bangladesh which could be increased by using industrially produced nitrogen fertilizers. But, use of these fertilizers has led to worldwide ecological problems as well as affects the human health (Vitousek, 1997).

The symbiotic nitrogen fixation resulting from the rhizobia-legume interaction can act as a renewable and environmentally 
sustainable source of nitrogen and can complement or replace fertilizer inputs (Peoples et al., 1995). Hence, only rhizobia that are specifically compatible with a particular species of legume can stimulate the formation of root nodules which in turn increase nitrogen fixation for better production of legume. Legumes encompass a variety of foods in pods including cowpea, beans, groundnut and lentils. They all contain protein as well as fiber, complex carbohydrates, healthy fats, potassium, iron and magnesium. In general, the world at present is confronted with the serious problems of food and nutrition deficiencies. Increased demand of proteins has led the research workers to search for getting overproduction of crops by exploiting better colonization of their root and rhizosphere through Rhizobium bacteria, which can reduce nitrogenous fertilizer use and can protect environment. However rhizobial inoculants which are produced commercially in have to be specific to legume species as well as to the region. Science native rhizobia are believed to be better adapted to local environmental conditions than commercial inoculants, we conducted a screening to select for the most efficient and competitive strain among indigenous rhizobia. Therefore, isolation and characterization of new Rhizobium strains are necessary for production of quality inoculant for using in cultivation of cowpea in Rajshahi, Bangladesh. In this study, indigenous Rhizobium strains were isolated from cowpea and then the isolates were characterized to uncover their suitability as a quality inoculant for cowpea cultivation at Rajshahi, Bangladesh.

\section{Materials and Methods}

\section{Isolation of Rhizobium strains}

The cowpea plants were collected from the Rajshahi, Bangladesh. Healthy, unbroken nodules of cowpea were used for isolation of root nodule bacteria (Rhizobium) with a method as described by Saha and Haque (2005). For the identification of the isolated bacterium, morphological characterization, microscopic observations, growth characteristics, biochemical tests and antibiotic sensitivity tests were performed with method described by Aneja (2003).

\section{Identification of Rhizobium strains by $16 \mathrm{~S}$ rDNA gene sequence}

Genomic DNA was extracted from the bacterial cells using TIANamp Bacteria DNA kit (Tiangen, China) and purified according to the manufacture's instruction. The amplification products were separated by electrophoresis of $10 \mu 1$. ( $7 \mu 1$ PCR product 3 $\mu l$ loading dye, Bromothymol blue) of the reaction product in $1.0 \%$ agarose gel $\left(\mathrm{wv}^{-1}\right)$ in Tris- instruction. The amplification products were separated by electrophoresis of $10 \mu 1$. (7 $\mu \mathrm{l}$ PCR product $3 \mu \mathrm{l}$ loading dye, Bromothymol blue) of the reaction product in $1.0 \%$ agarose gel $\left(\mathrm{wv}^{-1}\right)$ in Tris Borate buffer $(0.089 \mathrm{M}$ Tris, $0.089 \mathrm{M}$ boric acid, and 0.002M EDTA, pH 8), stained with ethidium bromide $(1.6 \mathrm{mg} / \mathrm{ml})$. The gel electrophoresis was carried out at $70 \mathrm{~V}$ at room temperature for 1.0 hour in electrophoresis unit (BioRad, USA) and DNA bands were visualized using UV transilluminator in gel documentation system. A $1 \mathrm{~kb}$ DNA ladder was used as molecular weight markers. The PCR products were purified using TIANquick Midi purification kit (Tiangen, China) according to the manufacture's protocol. The total DNA yield and quality were determined spectrophotometrically by Nano Drop 2000 (Thermo Scientific, USA). Sanger sequencing work flow using dye terminator technology was followed for the present study sequencing analysis was performed on a 800 bp PCR product. The sequence analysis was performed using the ABI 3130 genetic analyzer and Big Dye Terminator version 3.1 cycle sequencing kit. The 16S rRNA genes in 
the Gene Bank by using the NCBI Basic Local Alignment Search Tool (BLASTn) (http://www.ncbi.nih.gov/BLAST). distance matrix was generated using the Jukes-cantor corrected distance model. The phylogenetic trees were formed using Weighbor (Weighted Neighbor Joining: A likelihood-Based Approach to Distance-Based Phylogeny Reconstruction) with alphabet size 4 and length size 1000.The 16S rRNA gene sequences were deposited to Genbank using BankIt submission (Saitou and Nei, 1987).

\section{Effects of temperature and pH on bacterial growth}

Temperature and $\mathrm{pH}$ influence bacterial growth. For effect of $\mathrm{pH}$, culture medium was adjusted to $\mathrm{pH}$ 5.0, 7.0, and 9.0. Incubation temperature was varied at, 20, 28 and 37 ${ }^{0}$ C.For determination of effect of salinity, inoculated media were incubated at $1 \%, 2 \%$, $3 \%$ and $4 \%$ of $\mathrm{NaCl}$. Bacterial cell density of liquid cultures was determined by measuring optical density at $660 \mathrm{~nm}$ with photoelectric colorimeter (AE-11 M, Erma Inc., Tokyo) (Mohanta et al., 2012).

Seed and soil inoculation with Rhizobium and its effect on growth parameters in Cowpea

Seed inoculation was done by slurry method using adhesive (Saha and Haque, 2005). Then, inoculated seeds of Cowpea were sown in in pots. For soil inoculation, liquid culture of Rhizobium was sprayed thoroughly in inner part (1-1.5 inches below the surface) of soil in pots. Then, fresh and dry seeds of Cowpea were sown in pots. During the experiment the soils in pots were kept moistened.

\section{Statistical analysis}

Unless indicated otherwise, all experiments were independently conducted three times and data were pooled for presentation as mean \pm SEM. All data were analyzed with Prism software (GraphPad, La Jolla, CA, USA) using two-tailed unpaired Student's t-tests. Pvalues $<0.05$ were considered significant.

\section{Results and Discussion}

Bacteria were isolated by plating onto an agar solidified YEMA medium with Congored. The plates were incubated at $28^{\circ} \mathrm{C}$ for 2 days and bacterial colonies were found to grow on the medium. Results of microscopic analysis of bacterial cells and their growth characteristics are presented in Table 1 while the biochemical and antibiotics sensitivity tests of the bacterium are presented in Table 2, 3 respectively. Isolated bacterial strain was identified by both morphological and biochemical tests and this was further confirmed by $16 \mathrm{~S}$ rRNA gene sequence analysis. The strain showed 96\% (ID KF008235.1) homology with Rhizobium sp. SOY7.

Many previous studies reported isolation of Rhizobia of different strains from cultivated legumes, such as, Rhizobium leguminosarum stranis $S 17 / 2$ \& S 21/6 (Pohajda et al., 2016), $R$. tropici (Pinto et al., 2007), R. gallicum strain 8a3 (Mnasri et al., 2007). The soil bacterium Rhizobium sp. SOY7 that form nitrogen-fixing nodules on the roots of cowpea plant is being reported for the first time through this study.

In this study it was found that the colonies were circular, light pink, concave, entire and opaque. It was also observed that the bacterium was gram negative, rod shaped and motile. The isolates were showed hazy appearance in the motility media and also were positive for Catalase, Citrate utilization test, Urea hydrolysis, Congored test, Nitrification test, Oxidase test, Triple sugar iron test, MacConkey agar test and, Motility 
tests. This result is supported by the finding of Lupwayi and Haque (1994) and Allito (2015). The isolates were found negative for Methyl Red (MR), Voges-Proskauer (VP), Indole, Starch hydrolysis test, Hydrogen-sulfide production and Hofer's alkaline test. These findings are in close agreement with Elsheikh and wood (1986).

Utilization of different carbon sources is an effective tool to characterize the isolates (Mirza et al., 2007; Erum and Bano, 2008). In the present study sucrose, fructose, galactose, maltose and mannitol (25 mg Hi-media, India) and $20 \%$ solution of glucose, lactose, arabinose and xylose were utilized for this test. Isolates could utilize all the nine sugar. Similar results have been reported by some other paper (Stowers, 1983; Sadowsky et al., 1983).

Resistance patterns of the isolates to thirteen antibiotics were studied. Screening for antibiotic resistance in our study revealed that most of the isolates were resistance to Ampicilin, Erythromycin, Gentamicin, Amoxycillin, Penicillin, Streptomycin and Nalidixic acid. But, the isolates were sensitive to Mecillinam, Ciprofloxacin, Cotrimoxazole, Pefloxacin, Ceftazidime and Tetracycline which is agreed with the results of Jordan (1984) for the genus Rhizobium.

Table.1 Culture characteristics and microscopic observations of the isolated bacterial strain

\begin{tabular}{lll}
\hline Agar plates & Characters & Results \\
\hline YEMA slant & Abundance of growth & Moderate \\
& Colony & Circular, concave, entire, \\
& opaque \\
& Colour & Light pink \\
Microscopic observation & Gram staining & Gram-negative \\
& Motility & Motile \\
& Shaped & Rod shaped \\
\hline
\end{tabular}

Table.2 Biochemical test results for the isolated bacterial strain (Rhizobium sp. SOY7)

\begin{tabular}{llll}
\hline Biochemical test & Reaction & Sugar utilization & Reaction \\
\hline Catalase & + & Glucose & + \\
Citrate utilization & + & Sucrose & + \\
Urea hydrolysis & + & Fructose & + \\
Congored & + & Mannitol & + \\
Nitrification & + & & \\
Oxidase & + & & \\
Triple sugar iron & + & & \\
MacConkey & + & & \\
Methyl red & - & & \\
Voges-proskaure & - & & \\
Indole & - & & \\
Starch hydrolysis & - & & \\
Hydrogen sulfide & - & & \\
Hofer's alkaline & - & & \\
icrobial growth, - = no growth) & & & \\
\end{tabular}


Table.3 Antibiotic sensitivity tests

\begin{tabular}{lccc}
\hline Antibiotics & Disc distance $(\mathrm{mm})$ & $\mathrm{R}$ & $\mathrm{S}$ \\
\hline Mecillinam & 22 & - & $\mathrm{S}$ \\
Ampicilin & 5 & $\mathrm{R}$ & - \\
Ciprofloxacin & 30 & - & $\mathrm{S}$ \\
Erythromycin & 5 & $\mathrm{R}$ & - \\
Gentamicin & 6 & $\mathrm{R}$ & - \\
Cotrimoxazole & 26 & - & $\mathrm{S}$ \\
Amoxycillin & 6 & $\mathrm{R}$ & - \\
Penicillin & 5 & $\mathrm{R}$ & - \\
Pefloxacin & 21 & - & $\mathrm{S}$ \\
Ceftazidime & 23 & - & $\mathrm{S}$ \\
Streptomycin & 5 & $\mathrm{R}$ & - \\
Nalidixic acid & 5 & $\mathrm{R}$ & - \\
Tetracycline & 20 & - & $\mathrm{S}$ \\
\hline
\end{tabular}

Table.4 Effect of Rhizobium inoculation on various growth parameters in Cow pea

\begin{tabular}{|c|c|c|c|c|c|c|}
\hline & $\begin{array}{c}\text { Length } \\
(\mathrm{cms})\end{array}$ & $\begin{array}{l}50 \text { pod wt. } \\
\text { (gms) }\end{array}$ & $\begin{array}{c}100 \text { seed } \\
\text { wt. }(\mathrm{gms})\end{array}$ & $\begin{array}{c}\text { No. of } \\
\text { Nodules/ } \\
\text { Plant }\end{array}$ & $\begin{array}{c}\text { Fresh wt. of } \\
\text { nodules } \\
\text { (gms) }\end{array}$ & $\begin{array}{c}\text { Dry wt. of } \\
\text { nodules } \\
\text { (gms) }\end{array}$ \\
\hline Inoculated & $61.00 \pm 1.30$ & $\begin{array}{l}5.348 \\
\pm 0.05\end{array}$ & $7.376 \pm 0.13$ & $36.60 \pm 0.92$ & $0.1820 \pm 0.009$ & $0.0700 \pm 0.004$ \\
\hline $\begin{array}{l}\text { Control } \\
\text { Degrees of } \\
\text { freedom }\end{array}$ & $\begin{array}{c}53.60 \pm 0.67 \\
08\end{array}$ & $\begin{array}{c}4.570 \pm 0.02 \\
08\end{array}$ & $\begin{array}{c}6.096 \pm 0.05 \\
08\end{array}$ & $\begin{array}{c}30.80 \pm 0.73 \\
08\end{array}$ & $\begin{array}{c}0.1260 \pm 0.006 \\
08\end{array}$ & $\begin{array}{c}0.0440 \pm 0.008 \\
08\end{array}$ \\
\hline $\begin{array}{l}\text { Calculated } \\
\text { value. } \\
\mathrm{P}=0.05\end{array}$ & $0.0010^{* *}$ & $<0.0001^{* * *}$ & $<0.0001^{* * * *}$ & $0.0012^{* *}$ & $0.0009^{* * *}$ & $0.0231^{*}$ \\
\hline
\end{tabular}

Table.5 Properties of Cow pea soil types before and after inoculation with Rhizobium strain

\begin{tabular}{ccccc}
\hline Parameters & Units & Before use & Control & Inoculated \\
\hline $\mathrm{pH}$ & & 8.2 & 8.3 & 8.3 \\
Organic mater & $\%$ & 1.22 & 1.40 & 1.63 \\
Potassium & $\mathrm{Cmol} / \mathrm{kg}$ & 0.18 & 0.28 & 0.23 \\
Total Nitrogen & $\%$ & 0.07 & 0.08 & 0.10 \\
Phosphorous & $\mathrm{ppm}$ & 11.5 & 25.5 & 25.9 \\
Sulfur & $\mathrm{ppm}$ & 15.7 & 28.7 & 41.1 \\
Zinc & $\mathrm{ppm}$ & 2.47 & 4.94 & 5.20 \\
\hline
\end{tabular}


Fig.1 Effects of pH (a), temperature (b) and salinity (c) on bacterial growth
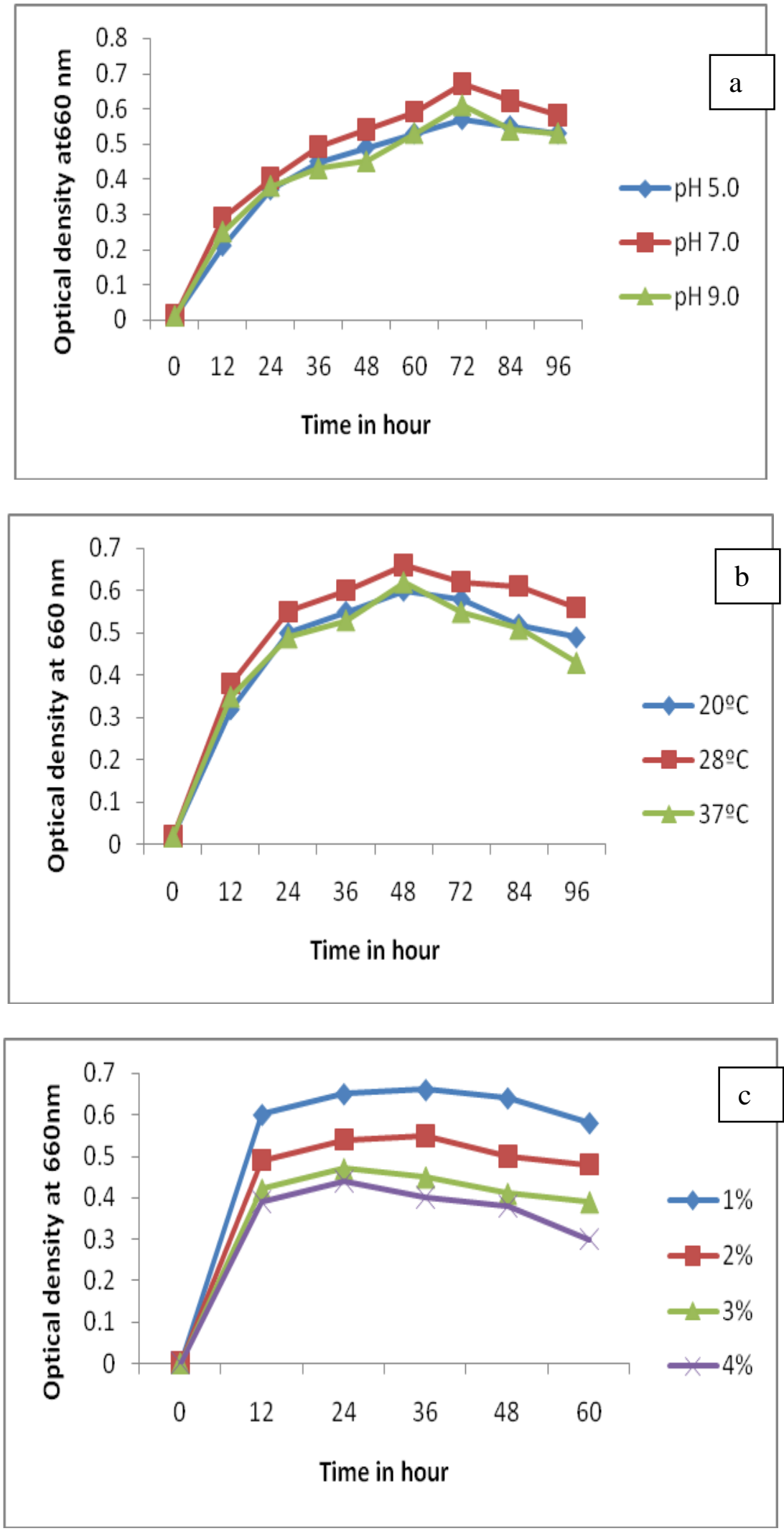
Fig.2 Unrooted phylogenetic tree showing the genetic relationship among the cultivated bacteria Cow pea and reference 16S rDNA sequences from the GenBank based on partial 16S ribosomal RNA gene sequences. Scale bar $0.02=2 \%$ difference among nucleotide sequences

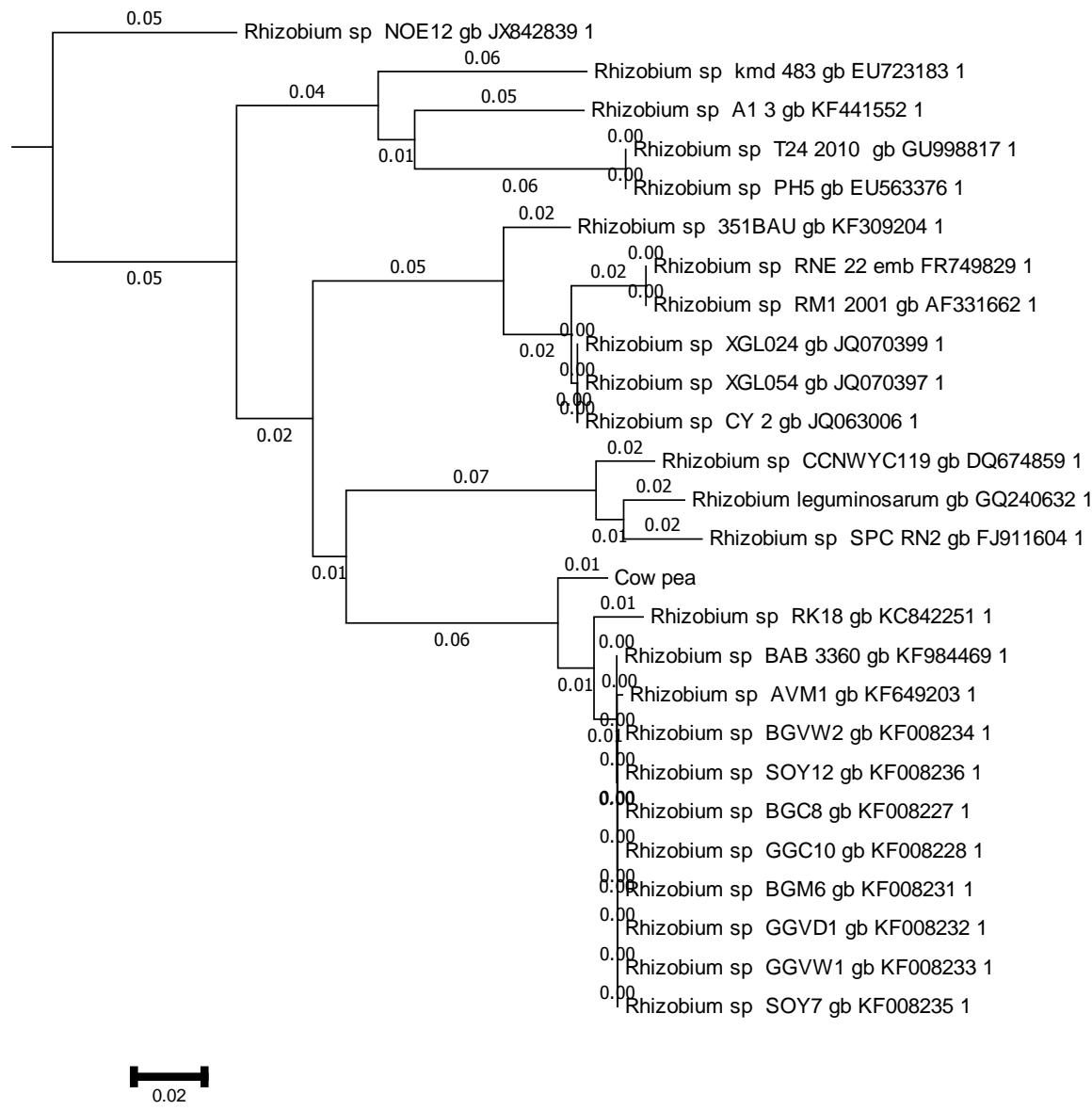

To verity the effects of temperature and $\mathrm{pH}$ of growth medium on the growth rate of the bacterium, a series of investigations were carried out which are presented in Fig. 1. The highest growth was observed at $28^{\circ} \mathrm{C}$ (Fig. 1b). The organisms were found to be temperature sensitive as at higher and lower temperatures, a low growth was observed that might be due to a hindrance in the metabolic activity. Similarly, the best growth of Rhizobium was found at pH 7 (Fig. 1a). Soil characteristics, such as $\mathrm{pH}$ and temperature, may compromise symbiotic efficiency and plant development. $\mathrm{pH}$ values below 5.0 are reported to be deleterious for nodulation and nitrogen fixation (Appunu and Dhar, 2006;
Mukherjee and Asanuma, 1998). Barberi et al., (2004) reported that the four strains of Bradyrhizobium isolated from Glycine max (BR29, SEMIA587), Vignaunguicuata (INPA3-11B) and Enterolobiumc ontortisiliquum (BR4406), all isolates were grown satisfactorily in $\mathrm{pH}$ values of 5.0, 6.0 and 6.8. The experiments also showed that the cells were able to grow at $1 \% \mathrm{NaCl}$ but unable to grow at higher concentration of $\mathrm{NaCl}$, showing that the isolate was sensitive to the salt concentration (Fig. 1c). Similar findings have been reported by Kucuk et al., (2006). In addition, Hashemandtheir colleagues in 1998 had proposed that salt stress may decrease the efficiency of the 
Rhizobium-legume symbiosis by reducing plant growth and photosynthesis.

In this study, the isolated bacteria were identified through $16 \mathrm{~S}$ rDNA gene sequencing. The $16 \mathrm{~S}$ rDNA sequence revealed that the isolated strain was homologous to bacterial strain Rhizobium sp. SOY7. The phylogenetic distances shown in Figure 2 indicate that the relationships between this group and the Agrobacterium species. Moreover, this phylogenetic tree clearly showed that the isolates were belonged to the genus Rhizobium.

The results obtained in this study show some interesting aspects on the growth effects of Rhizobium inoculation on Cowpea, which was grown in pots under controlled environment. For all studied parameter of Cowpea growth viz. number, fresh weight and dry weight of nodules, plant height, pod weight and seed weight, the result showed significant differences between inoculation and control plants (Table 4). These findings can be supported by other studies as reported that Rhizobial inoculation induced significant changes in plant growth characteristics (Sharma and Tilak, 1974; Kapur et al., 1975; Dev and Tilak, 1976).

Plant growth and microorganism activity depends upon soil reaction and on possible condition of the soil. Hence, soil properties of pots in which the Cowpea were cultivated were tested. It was found that Rhizobium inoculation can increase amount of Sulfur remarkably in soil (Table 5). Conversely, the amount of Potassium was decreased significantly in soil after Rhizobium inoculation. However, no remarkably changes were observed in other parameters of soil after Rhizobium inoculation (Table 5). Likewise, it was reported that Rhizobium inoculation in Cowpea enhanced the plant soil properties than control in line with Tabatabai (1994).
The indigenous strain Rhizobium sp. SOY7 which was isolated from cowpea of Rajshahi, Bangladesh possesses some unique characteristics of carbohydrate utilization, antibiotic resistance, salt tolerance and optimal growth condition. Altogether it can be concluded from this study the isolated indigenous Rhizobium sp. SOY7 strain could be an efficient candidate for production of biofertilizer for using in Rajshahi, Bangladesh as it shows some positive aspect on the growth of cowpea in this region.

\section{Acknowledgements}

The Author is thankful to Centre for Advanced Research in Science (CARS) under Dhaka University, Bangladesh for technical assistance for bacteria identification.

\section{References}

Allito, B.B., 2015. Soil population and phenotypic characterization of soybean (Glycin max) and haricot bean (Phaseolus vulgaris) nodulating rhizobia at Hawassa and Ziway. Scholarly Journal of Agricultural Science, 5(1): 30-38.

Aneja, K. R., 2003. Experiments in microbiology plant pathology and Biotechnology, 4th edition, New age International Publishers, New Delhi, India.

Appunu, C., and Dhar, B. 2006. Symbiotic effectiveness of acid-tolerant Bradyrhizobium strains with soybean in low $\mathrm{pH}$ soil. African Journal of Biotechnology, 5:842-845.

Barberi, A., Moreira, F.M.S., Florentino, L.A., Rodrigues, M.I.D. 2004.Growth of Bradyrhizobium elkanii Strain BR 29 in culture media with different $\mathrm{pH}$ values.Ciênciae Agrotecnologia,28:397405.

Dev, S.P., and Tilak, K.V.B.R. 1976. Effect of organic amendments on the 
nodulation and nitrogen fixation by soybean. Indian. J. Agric. Research., 46(6): 252-256.

Elsheikh, E.A.E., and Wood, M. 1986. Soil biology. Biochem, 21: 883-887.

Erum, S., and Bano, A. 2008.Bariation in phytohormone production in Rhizobium strains at different altitudes of Northern areas of Pakistan. Int. J. Agric. Biol., 10: $536-540$.

Hashem, F.M., Swelim, D.M., Kuykendall, L.D., Mohamed, A.I., Abdel-Wahab, S.M., Hegazi, N.I. 1998. Identification and characterization of salt and thermo tolerant Leucaenamodulating Rhizobium strains. Biol. Fert.Soil, 27: 335-341.

Jordan, D.C., 1984. Family III.Rhizobiacea Conn 1938. In: Bergey's Manual of Systermnatic Bacteriology. Bol I (eds Krieg. N.R. and Holt. J.G) Wilhams and Wilkings Press, Baltimore, pp. 234-254.

Kapur, O.C., Ganguwar, M. S., Tilak, K.V.B.R. 1975. Influence of zinc on symbiotic nitrogen fixation by soybean (Glycine max Linn.) in silt loam soil. IJAR, 9 (1):51-56.

Kiers, E.T., West, S.A., Denison, R.F. 2002. Mediating mutualisms farm management practices and evolutionary changes in symbiont co-operation. $J$. Appl. Ecol., 39: 745-754.

Kucuk, C.M., Kivanc, M., Kinaci, E. 2006. Characterization of Rhizobium sp. Isolated from Bean. Turk J. Biol.,30: $127-132$

Lupwayi, N., and Haque, I. 1994. LegumeRhizobium technology manual Environmental sciences division International Livestock center for Africa, Addis Ababa, Ethiopia, pp.1-93.

Mirza, B.S., Mirza, M.S., Bano, A., Malik, K.A. 2007.Coinoculation of chickpea with rhizobium isolates from roots and nodules and phytohormone producing enterobacter strains, Aus. J. Exp. Agric.,47(8): 1008-1015.
Mnasri, B., Tajini, F., Trabelsi, M., Aouani, M.E., Mhamdi, R. 2007. Rhizobium gallicum as an efficient symbiont for bean cultivation. Agron. Sustain. Dev., 27:331-336.

Mohanta, M.K., Saha, A.K., Zamman, M.T., Ekram, A.E., Khan, A.E., Mannan, S.B., Fakruddin, M. 2012. Isolation and characterization of carbofuran degrading bacteria from cultivated soil. Biochem. Cell. Arch., 12 (2): 313-320.

Mukherjee, S.K., and Asanuma, S. 1998. Possible role of cellular phosphate pool and subsequent accumulation of inorganic phosphate on the aluminum tolerance in Bradyrhizobium japonicum. Soil Biology and Biochemistry, 30:1511-1516.

Ngakou, A., Megueni, C., Ousseni, H., Massai, A. 2009. Study on the isolation and characterization of rhizobia strains as biofertilizer tools for growth improvement of four grain legumes in Ngaoundéré-Cameroon. Int. J. Biol. Chem. Sci., 3(5): 1078-1089.

Pinto, F.G.S., Hungria, M., Mercante, F.M. 2007.Polyphasic characterization of Brazilian Rhizobium tropici strains effective in fixing $\mathrm{N}_{2}$ with common bean (Phaseolus vulgaris L.). Soil Biology and Biochemistry, 39: 18511864.

Pohajda, I., Babić, K.H., Rajnović, I., Kajić, S., Sikora, S. 2016. Genetic diversity and symbiotic efficiency of indigenous common bean Rhizobia in Croatia. Food Tecjnol. Biotechnol, 54(4): 468474.

Sadowsky, M.J., Keyser, H.H., Bohlool, B.B. 1983. Biochemical characterization of fast growing and slow growing rhizobia that nodulate soybeans. Syst. Bacteriol., 33: 716-722.

Saha, A.K., and Haque, M.F. 2005.Effect of inoculation with Rhizobium on nodulation and growth of Bean, 
Dolchos lablab. J. Life Earth Science, 1(1): 71-74.

Saitou, N., and Nei, M. 1987. The Neighborjoining method: A new method for reconstruction Phylogenetic trees. Molecular biology and Evolution, 4(4): $406-425$.

Sharma, D.S., and Tilak, K.V.B.R. 1974. Comparative efficiency of different commercial inoculants of Rhizobium japonicum on field grown soybeans. ICAR, 8(4): 223-226.

Stowers, M.I., and Eaglesham, A.R.J. 1983.A stem nodulating Rhizobium with physiological characteristics of both fast and slow growers. J. Gen. Microbiol., 129: 3651-3655.

Tabatabai, M.A., 1994.Soil enzymes. In: Methods of soil Analysis Part 2. Microbiological and Biochemical properties. Ed : Weaver RW, Angle S, Bezdicek D, Smith S, Tabatabai, M. A, Wollum, A Soil Science society of America Book Series., 5, pp.775-834.

Vitousek, P.M., 1997. Human alteration of the global nitrogen cycle: sources and consequences, Ecological Applications., 7: 737 .

\section{How to cite this article:}

Ali Mohammad Nushair, Ananda Kumar Saha, Md. Anisur Rahman, Moni Krishno Mohanta and Md. Fazlul Haque. 2017. Genotypic Characterization of Indigenous Rhizobium Strain from Cultivated Cowpea (Vigna unguiculata L.) in Bangladesh. Int.J.Curr.Microbiol.App.Sci. 6(10): 2493-2502. doi: https://doi.org/10.20546/ijcmas.2017.610.293 